\title{
WATER USE EFFICIENCY, BIOMASS PRODUCTION, NITROGEN AND POTASSIUM UPTAKE AND YIELD OF TOMATO (LYCOPERSICON ESCULENTUM CV.RATAN) PLANTS GROWN UNDER SURFACE DRIP AND FLOOD IRRIGATION
}

\author{
A.H.M.Z. ALI AND M.K. RAHMAN \\ Department of Soil, Water \& Environment, University of Dhaka, Dhaka-1000, Bangladesh.
}

\begin{abstract}
An experiment was conducted in wooden boxes to evaluate water use efficiency, biomass production, nitrogen and potassium uptake and yield of tomato plants (Lycopersicon esculentum) grown under flood irrigation (FI) and surface drip irrigation (SDI). Leaf area, leaf area index, biomass production and yield of tomato plants were significantly $(\mathrm{P}<0.05)$ higher in SDI than FI treatment. Biomass production $(\mathrm{g} / \mathrm{plant})$ was 53.3 and 42.2 and yield of tomato (kg/plant) was 1.27 and 0.99 in SDI and FI treatments, respectively. Surface drip irrigation increased water use efficiency $\left(\mathrm{Kgm}^{-3}\right)$ of tomato plants by two fold (37.88) compared to flood irrigation ( 19.88). Significantly $(\mathrm{P}<0.05)$ higher concentrations of nitrogen in leaf $(3.22 \%)$ and stem $(2.62 \%)$ were measured for tomato plants grown under SDI than FI (2.63 and $2.19 \%$ ). Potassium concentrations on the other hand, showed no significant differences.
\end{abstract}

Key words: Surface drip irrigation, Flood irrigation, Super typhoon, Water use efficiency

\section{Introduction}

The increased competition for water between agricultural, industrial and urban consumers necessitates continuous improvement of irrigation practices and fundamental changes in irrigation management or application of water saving methods. Also, the irrigation practices are now encouraged to minimize nutrient losses to the environment with particular emphasis on ground water contamination and cultural eutrophication (Sezen et al. 2006).

The most common method of applying water is flood irrigation, proved cost ineffective and water use inefficient. On the other hand, water saving method like drip irrigation has been shown to be effective for growing crops by different researchers (Sharmasarkar et al. 2001, Camp et al. 1989 and Hutmacher et al. 1996). The method can be applied for optimal soil moisture, for crop growth, increased crop water use efficiency, improved crop yield and quality, increased interaction of irrigation and fertilizer applications on crop growth, unsaturated soil water movement, irrigation water quality and the movement and distribution of salt in the root- zone and irrigation system design and management (Sarker and Haldar 2010, Michael 1996, Bihery and Lachmar 1994 and Comis 2011). 
Irrigation methods for growing tomato in Bangladesh are flooding, furrow and basin. In general, farmers of Bangladesh are used to over irrigate tomato plants resulting in high water losses and low irrigation efficiencies. Surface drip Irrigation (SDI) has never practiced as an effective method for growing tomato in Bangladesh. Therefore, the present investigation was undertaken to compare and evaluate water use efficiency, growth and yield of tomato plants (local variety) grown under surface drip and flood irrigation.

\section{Materials and Methods}

Soil collection: Soils were collected from the bank of the river Turag (Near Baliarpur, Savar) at a depth of $0-15 \mathrm{~cm}$, air-dried, processed and kept in plastic bags prior to set up of the experiment. The experiment was carried out in the net house of the Department of Soil, Water and Environment, University of Dhaka, Bangladesh. The soil had a $\mathrm{pH}$ of 6.5 , and water holding capacity $33 \%$, particle size distribution- $25 \%$ sand, $64 \%$ silt and $11 \%$ clay and texture silt loam. Available nitrogen and exchangeable potassium in soils were $1.4 \mathrm{mg} / 100 \mathrm{~g}$ soil and $30 \mathrm{mg} / \mathrm{kg}$ soil, respectively. Soil $\mathrm{pH}$ was measured electrometrically using Corning Glass Electrode $\mathrm{pH}$ meter at a soil:water ratio of 1:2.5 (Jackson 1958). Hydrometer method was used for the particle size distribution of soil (Bouyoucos 1962). Available nitrogen content in soil was determined following the methods as described by Marr and Cresser (1983) and exchangeable potassium by Jackson (1958).

Preparation of boxes: Six wooden boxes $(122$ X 25 X $30 \mathrm{~cm})$ were constructed for the experiment. In order to prevent water loss and/ or addition of water, outer sides of the boxes were coated with water proof paint. A white polythene sheet with the same size of the wooden box was placed in the box and filled with the collected air-dry soil. A basal dose of N: P: K fertilizers at the rate of 60: 18: $38 \mathrm{~kg} / \mathrm{ha}$ (BARC 2005) as urea, triple super phosphate (TSP) and muriate of potash (MP) was applied in each box and mixed thoroughly. A polythene shade was constructed to save the boxes from climate hazard.

Experimental Design: There were: (a) two different irrigation techniques employed, i. e., (i) SDI = surface drip irrigation with pipe set up on the surface of the soil $(0 \mathrm{~cm}$ depth) to supply water in the root zone and ; (ii) FI = flood irrigation, applying water on the soil surface; (b) one cultivar (CV), local tomato variety (Ratan) as a test crop. One variety (CV), two irrigation methods (IR) were replicated (R) three times. Therefore, 2 (IR) X 1 (CV) $\mathrm{X} 3(\mathrm{R})=6$ boxes were used in the experiment. Boxes were arranged in a completely randomized design.

Drip irrigation set up: In front of each boxes a plastic container (10 litre) with an outlet (bib cock) of water was set up on top of the steel bar of the net house. A plastic pipe was then joined to the bib cock of the container and made it long up to the ground level of the wooden boxes. Drip irrigation pipes super typhoon 100 unit $40 \mathrm{~cm}$ distance between 
drippers (Netafim Israel) were joined with the plastic pipes using hose clamp. To know the moisture status of the soil, a tensiometer was set up in one box in each treatment at 20 $\mathrm{cm}$ depth and readings were recorded every day at 10:00 am to maintain the field capacity $(-10 \mathrm{kPa})$. The matric potential of soil that corresponds best to water content at field capacity is $-10 \mathrm{kPa}$ (Marshall and Holmes 1992). Water was applied to each box when the tensiometer turned down below field capacity and left for two hours to reach equilibrium. A total amount of 55.25 and $33.5010^{-3} \mathrm{~m}^{3}$ water were applied in FI and SDI treatments, respectively. Water use efficiency was determined as the ratio of total biomass yield for a particular treatment to the applied volume of water for that treatment (Howell et al. 1995).

Transplantation of seedlings: Seeds of tomato (local variety, Ratan) supplied by Lal Teer Seed Limited, Bangladesh were used in this experiment. Before germination, seeds were soaked in water for 24 hours and allowed to germinate on soil for 7 days in the dark at $27^{\circ} \mathrm{C}$. Germinated seeds were then transferred in small plastic containers filled with soil and allowed to grow for one month. One month old seedlings @ 3 per box were transplanted keeping a distance of $40 \mathrm{~cm}$ (drip point) between plant to plant, running north to south.

Leaf area, leaf area index, fresh and dry weight of leaf and stem: Leaf area (length $\mathrm{x}$ width) was measured with the help of a ruler. Leaf area index (LAI) was calculated as a ratio between leaf area and ground area. Fresh weight of tomato leaf and stem was taken just after collection of the whole plant with the help of a digital electric balance. Collected plant samples (both leaf and stem) were air dried and finally dried in an oven at $60-65^{\circ} \mathrm{C}$ for 48 hours and dry weight was taken.

Determination of Nitrogen and Potassium: For total nitrogen and potassium analysis, $0.1 \mathrm{~g}$ ground leaves and stems were digested with $5 \mathrm{ml}$ concentrated $\mathrm{H}_{2} \mathrm{SO}_{4}$ and $2 \mathrm{ml} \mathrm{4 \%}$ (v/v) solution of perchloric acid (62\%). The digest was cooled and diluted to $100 \mathrm{ml}$ with deinonised water. The concentration of nitrogen in leaves and stems was determined following steam distillation in the presence of $40 \% \mathrm{NaOH}$ and titrated with $\mathrm{HCl}$ (Cresser and Parsons 1979). The concentrations of potassium in leaves and stems were determined by feeding the extract into a flame photometer.

Statistical Analysis: Statistical analysis was made using SPSS version 15.0.

\section{Results and Discussion}

Soil water potential: Variation in soil water potential during experimental period in different boxes is presented in Fig. 1. Lowest and highest values of soil water potential were 8.6-11.2 and 9.0-11.2 in Box-1 and Box-4 in SDI and FI treatments, respectively. Average values of soil water potential were 9.8 and $9.7 \mathrm{kPa}$ in Box-1 and Box-4, respectively. 


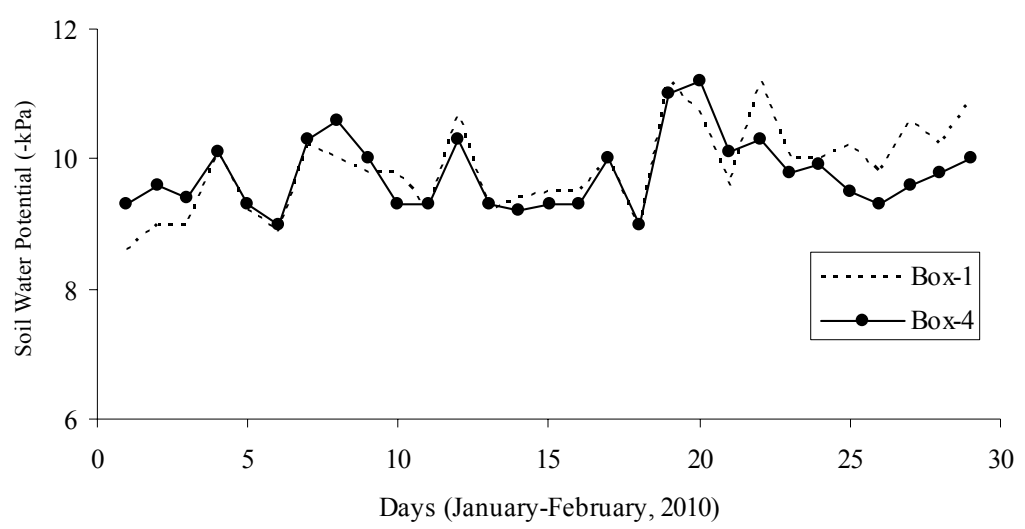

Fig.1. Variation in soil water potential during experimental period in different boxes.

Biomass production: Effects of surface drip and flood irrigation on fresh and dry weight of leaf of tomato are shown in Fig. 2 (a) and (b), respectively. Significant $(\mathrm{p}<0.05)$ effects between surface drip and flood irrigation were observed for fresh and dry weight of leaves of tomato. In case of stem of tomato, only the dry weight of stem was significantly $(\mathrm{p}<0.05)$ higher in SDI than FI (Fig.3). Leaf area of tomato was significantly $(\mathrm{P}<0.05)$ higher in drip $(\mathrm{SD})$ than flood irrigation $(\mathrm{FI})$ (Table 1). Leaf area index was also significantly $(\mathrm{P}<0.05)$ higher in $\mathrm{SD}$ than FI treatment. Total dry weight of tomato $($ leaf + stem) was also significantly $(\mathrm{P}<0.05)$ higher in SDI than FI treatment (Fig.3). Higher dry matter yield was reported by Moreshet et al. (1996) and Ertek and Kanber (2001) for cotton plants grown under surface drip irrigation. Higher depth of drip irrigation also reported to increase fresh weight of bell pepper and was explained better water use efficiency of drip irrigation method (Dalla Costa and Gianquinto 2002).

Table 1. Effects of surface drip and flood irrigation on leaf area, leaf area index, yield and water use efficiency for tomato.

\begin{tabular}{lcccc}
\hline Treatments & $\begin{array}{c}\text { Leaf Area } \\
\left(\mathrm{m}^{2}\right)\end{array}$ & $\begin{array}{c}\text { Leaf area } \\
\text { index }\end{array}$ & $\begin{array}{c}\text { Yield } \\
(\mathrm{g} / \text { plant })\end{array}$ & $\begin{array}{c}\text { Water use } \\
\text { efficiency } \\
\left(\mathrm{Kgm}^{-3}\right)\end{array}$ \\
\hline SD & $0.304^{\mathrm{a}}$ & $2.4^{\mathrm{a}}$ & $1269^{\mathrm{a}}$ & $37.88^{\mathrm{a}}$ \\
FI & $0.277^{\mathrm{b}}$ & $2.2^{\mathrm{b}}$ & $999^{\mathrm{b}}$ & $19.88^{\mathrm{b}}$ \\
\hline
\end{tabular}

${ }^{\mathrm{a}, \mathrm{b}}$ Data bearing different subscripts within the same column differ significantly $(\mathrm{P}<0.05)$.

Water use efficiency (WUE): Significantly higher WUE values $(\mathrm{P}<0.05)$ were recorded for SDI than FI in the present investigation (Table 1). Water use efficiency values for drip irrigation were always found to be greater than those for flood irrigation for sugerbeets (Sharmasarkar et al. 2001). WUE increased with increasing water table depth 
in bell pepper (Capsicum annum L.) (Dalla Costa and Gianquinto 2002). Besides, plant growth is the integrated product of abiotic properties of the environment and numerous biologically mediated chemical reactions that occur in soil and plant. Water use by plants is controlled mainly by the abiotic properties of the environment in which they grow (Power 1983). In flood irrigation method, losses of water occur mainly in the conveyance, application, percolation, evaporation and runoff which are reduced in drip irrigation method (Hansen et al. 1987). Hence, drip irrigation performed better with higher water use efficiency of tomato.

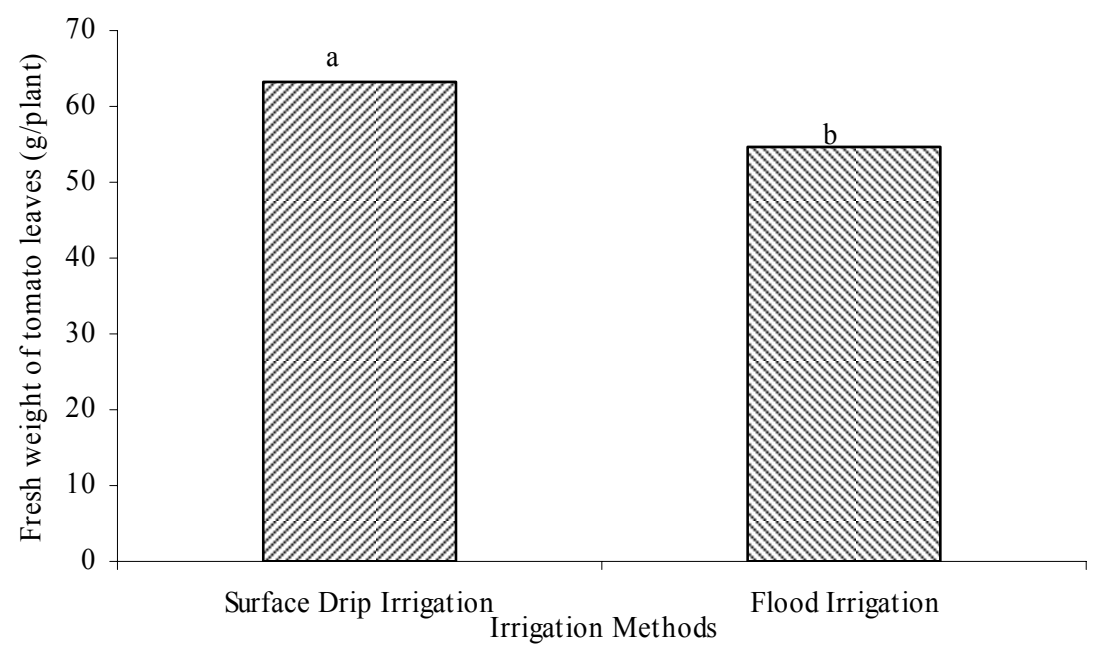

(a)

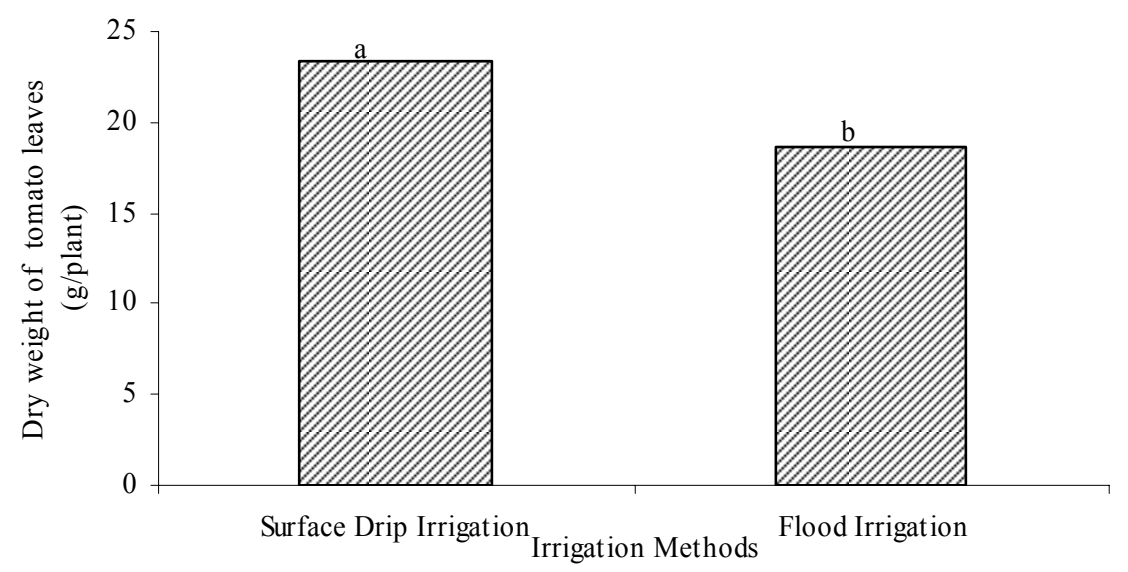

(b)

Fig. 2. Effects of surfacedrip and flood irrigation on (a) fresh weight and (b) dry weight of leaves of tomato. Values that differ significantly $(\mathrm{P}<0.05)$ expressed by different letters. 


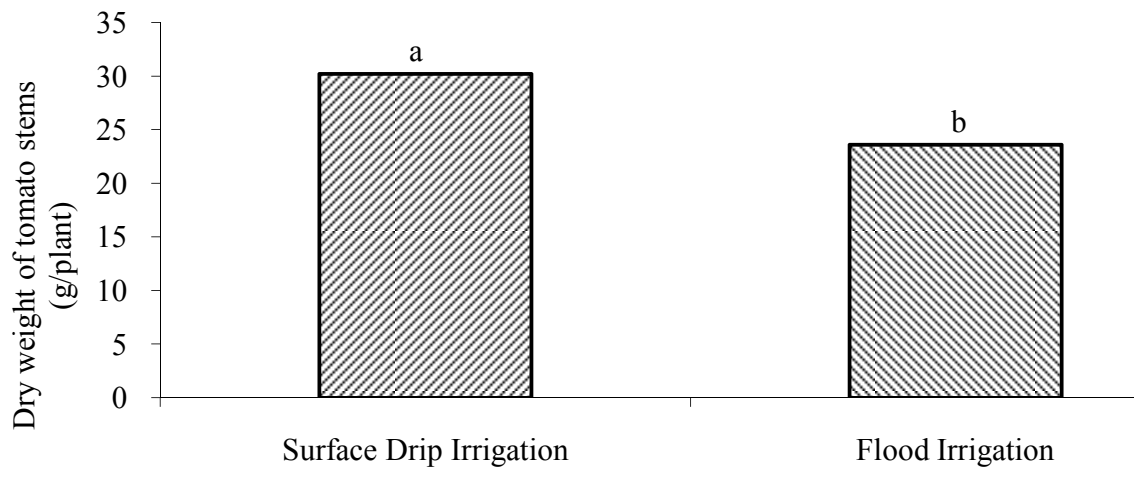

Irrigation Methods

(a)

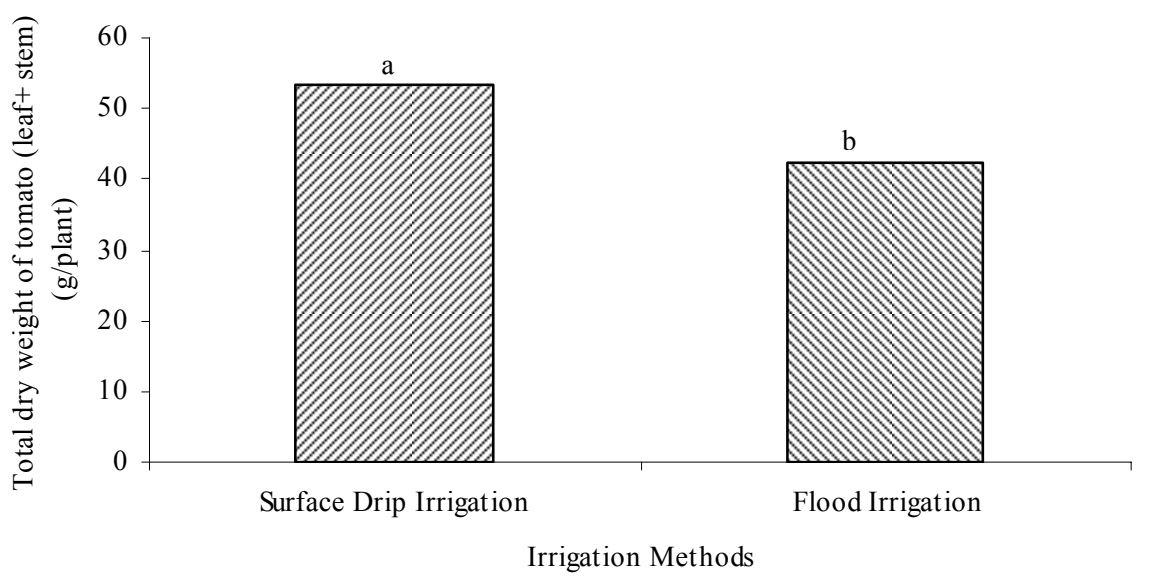

(b)

Fig. 3. Effects of surface drip and flood irrigation on (a) dry weight of stem of tomato and (b) total dry weight $($ leaf + stem $)$. Values that differ significantly $(\mathrm{P}<0.05)$ expressed by different letters.

Total nitrogen $(N)$ concentration of leaf and stem: Effects of surface drip and flood irrigation on total nitrogen concentration of tomato leaf and tomato stem are presented in Figs. 4 (a) and (b), respectively. In this case, total $\mathrm{N}$ concentration of leaf and stem of tomato was significantly $(\mathrm{P}<0.05)$ higher in SDI than FI treatment. Higher nitrogen concentration in the leaves of tomato plants grown under drip irrigation was reported by Badr and Abou El-Yazid (2007). Geleta et al. (1994) compared drip and flood irrigation 
and concluded that drip irrigation resulted in lower $\mathrm{NO}_{3}{ }^{-} \mathrm{N}$ loss. Nutrient transport from the soil solution to the root surface takes place by two simultaneous processes: convection in water flow and diffusion (Junk 1996). Mobile $\mathrm{NO}_{3}-\mathrm{N}$ ion supply is taken up by plant roots mainly through convection in water flow. Emitters in the drip irrigation pipes deliver water directly to the soil near the plant and maintains moisture within the root zone of a plant (Hansen et al. 1979). As a result, nitrogen uptake by plants might be higher in surface drip than flood irrigation.

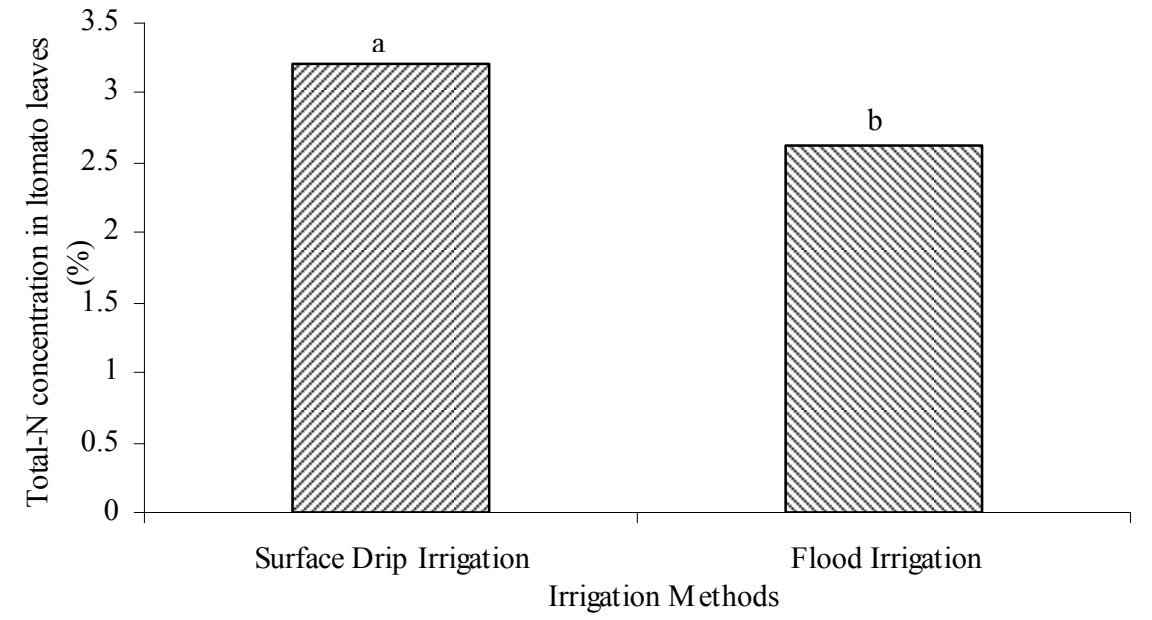

(a)

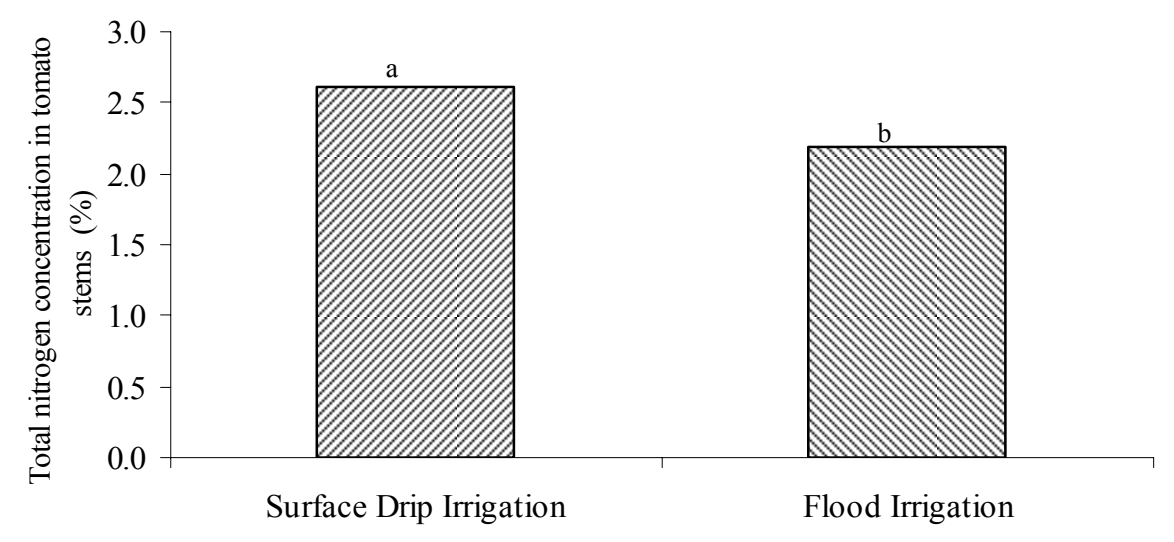

Irrigation Methods

(b)

Fig. 4. Effects of surface drip and flood irrigation on the total nitrogen concentrations (a) leaves of tomato and (b) stem of tomato. Values that differ significantly $(\mathrm{P}<0.05)$ expressed by different letters. 
Total potassium $(K)$ concentration of leaf and stem: Mean values of total $\mathrm{K}$ concentration in leaf were 17.0 and $18.0 \mathrm{ppm}$ and in stem 24.8 and $20.9 \mathrm{ppm}$ for SDI and FI treatments, respectively. No significant $(\mathrm{P}>0.05)$ differences were obtained between surface drip and flood irrigation. Diffusion is the governing mechanism for the less mobile nutrient potassium (Mmolawa and Or 2000). As a result, surface drip water application might have no significant effect on potassium contents of tomato plants.

Yield : Effects of surface drip and flood irrigation on the yield of tomato are presented in Table 1. Yield of tomato ( $\mathrm{kg} / \mathrm{plant})$ was also significantly $(\mathrm{P}<0.05)$ higher in SDI (1.27) than FI (0.99) treatment. Data show yield of tomato is about 1.28 times higher in surface drip than flood irrigation. Dalla Costa and Gianquinto (2002) stated that bell pepper yield was affected by water limitation and could benefit from abundant irrigation especially if applied as drip irrigation. Among the advantages of drip irrigation the most important are high water application efficiency and minimized nutrient loss due to localized application of water. Doorenbos and Kassam (1979) indicated that the maximum corn and cotton yields were obtained when irrigated at available water capacity. Sainju et al. (2001) reported a positive response of surface drip irrigated tomato yield to increasing nitrogen rates. In the present investigation surface drip irrigation also increased the nitrogen concentration in tomato plants and increased its yield.

\section{Acknowledgements}

The authors are grateful to the Director of Centre for Advanced Studies and Research in Biological Sciences, University of Dhaka for providing the fund for this experimental work, to Mr. G.M. Mohsin, Lal Teer Seed Limited, Plant and R \& D Farm, Gazipur, Dhaka for supplying tomato seeds, also to Dr. K. Ozawa and Dr. Ken Nakamura of Okinawa Subtropical Station of Japan International Research Centre for Agricultural Sciences (JIRCAS), Japan for their generous help providing tensiometer and drip irrigation pipes for this experiment.

\section{References}

Badr, M. A. and A. A. Abou El-Yazied. 2007. Effect of fertigation frequency from subsurface drip irrigation on tomato yield grown on sandy soil. Aust. J. Basic \& Appl. Sci. 1(3): 279-285.

Bangladesh Agricultural Research Council (BARC). 2005. Fertilizer Recommendation Guide. BARC Soils Publication No.45. Peoples Press \& Publications, Purana Paltan, Dhaka. pp.107.

Bouyoucos, G. J. 1962. Hydrometer method improved for making particle analysis of soil. Agron. J. 54: 464-465.

Bihery, M. A. and T.E. Lachmar. 1994. Ground water quality degradation as a result of over pumping in the delta Wadi El-Arish area, Sinai Peninsula, Egypt. Environ. Geol. 24: 293305.

Camp, C. R., E. J. Sadler and W. J. Busscher. 1989. Subsurface and alternate- middle micro irrigation for the southeastern Coastal Plain. Transactions of the ASAE. 32: 451- 456.

Comis, D. 2011. Growing crops and saving water in the west. Agricultural Research. 59(7):12-13. 
Cresser, M. and J. W. Parsons. 1979. Sulphuric-percholric acid digestion of plant material for the determination of nitrogen, phosphorus, potassium, calcium and magnesium. Anal Chim Acta. 109: 431-436.

Dalla Costa, L. and G. Gianquinto. 2002. Water stress and water table depth influence yield, water use efficiency, and nitrogen recovery in bell pepper: Lysimeter studies. Aust. J. Aric. Res. 53: 201-210.

Doorenbos, J. and A.H. Kassam. 1979. Yield response to water. FAO Irrigation and Drainage Paper. N0. 33. Rome, Italy. 193 pp.

Ertek, A. and R. Kanber. 2001. Effects of different irrigation programs on the growth of cotton under drip irrigation. Turkish J. Agric. Forest. 25: 415-425.

Geleta, S., G. J. Sabbagh, J. F. Stone, R. L. Elliot, H. P. Map, D. J. Bernardo and K. B. Watkins. 1994. Importance of soil and cropping systems in the development of regional water quality policies. J. Environ. Qual. 23: 36- 42.

Hansen, V.E., O.W. Israelsen and G.E. Stringham. 1979. Irrigation Principles and Practices. $4^{\text {th }}$ ed. John Wiley \& Sons, Singapore. 417 pp.

Howell, T. A., A. Yazar, A. D. Schneider, D. A. Dusek and K. S. Copeland. 1995. Yield and water use efficiency of corn in response to LEPA irrigation. Transactions of the ASAE. 38(6): 1737-1747.

Hutmacher, B., R. Mead and P. Shouse. 1996. Subsurface drip: improving alfalfa irrigation in the west. Irrigation Journal. 46: 48- 52.

Jackson, M. L. 1958. Soil Chemical Analysis. Printice-Hall, Englewood Cliffs, N.J., USA. 498 pp.

Junk, A. O. 1996. Dynamics of nutrient movement at soil-root interface. In: Plant Roots-The Hidden Half. $2^{\text {nd }}$ edition. (eds. Y. Waisel, A. Eshel and U. Kafkafi). pp.529-556, Marcel Dekker, Inc. New York.

Marr, I.L. and M.S. Cresser. 1983. The Lithosphere. In: Environmental Chemical Analysis. pp.155182, Blackie \& Sons, UK.

Marshall, T. J. and J. W. Holmes. 1992. Soil Physics. Athenaeum Press Ltd., UK. 256 pp.

Michael, A. M. 1996. Irrigation- Theory and Practice. Vikas Publishing House Pvt. Ltd. New Delhi, India. $801 \mathrm{pp}$.

Mmolawa, K. and D. Or. 2000. Root zone solute dynamics under drip irrigation: a review. Plant and Soil. 222: 163-190.

Moreshet, S., M. Fuchs and Y. Cohen. 1996. Water transport characteristics of cotton as affected by drip irrigation. Agron. J. 88: 717-722.

Power, J. F. 1983. Soil management for efficient water use: Soil fertility. In: Limitations to efficient water use in crop production (ed. H. M. Taylor). pp.461-470. ASA-CSSA-SSSA, Madison, WI 53711, USA.

Sainju, U.M., B.P. Singh and W.F. Whitehead. 2001. Comparison of the effects of cover crops and nitrogen fertilization on tomato yield, root growth and soil properties. Science Horticulture. 91: 201-214.

Sarkar, D. and A. Haldar. 2010. Physical and Chemical Methods in Soil Analysis. $2^{\text {nd }}$ ed. New Age International Publishers. India. $211 \mathrm{pp}$.

Sezen, S.M., A. Yazar and S. Ekber. 2006. Effect of drip irrigation regimes on yield and quality of field grown bell pepper. Agric. Water Management. 81 (1-2): 115-131.

Sharmasarkar, F. C., S. Sharmasarkar, S.D. Miller, G.F. Vance and R. Zhang. 2001. Assessment of drip and flood irrigation on water and fertilizer use efficiencies for sugarbeets. Agric. Water Management. 46: 241- 251. 